\title{
Unpacking Multilingualism in Tourism Peripheries in Bali: Taking a Look into Private Shop-fronts
}

\author{
Dewianti Khazanah ${ }^{1}$, Reni Kusumaningputri ${ }^{2}$ \\ University of Jember, INDONESIA \\ e-mail: dewiantikhazanah.sastra@unej.ac.id ${ }^{1}$, reni.fib@unej.ac.id ${ }^{2}$
}

\begin{abstract}
This article reports on the discussion of linguistic landscape in the course of tourism peripheries. The central aim is to unravel the salience and visibility of languages manifested in the shop-fronts in Bali tourism peripherals. This disclosure explains how the stakeholders in multilingual Bali tourism peripheries perceive vitality of the languages coexisting in these areas. Drawing on Bourdieu's language as social power (1983; 1993), presentation-of-self (Goffman, 1963; 1981), and good-reasons perspective (Boudon, 1990) the language choices made by the local shop owners and the principles driving these choices were explored. The findings conclude that English is the dominant language in Bali tourism peripheries, and it is driven by the perceived power attributed to English and the economic benefits associated with it; meanwhile, the principle of presentationof-self is not prioritized. We argue that local shop owners' perception of targeted clients is the determining factor influencing it. Some implications are made in this study.
\end{abstract}

Keywords: Language choice; language as social power; linguistic landscape.

\section{INTRODUCTION}

Tourism in every country is a form of global trading. With mobility as its nature (Williams \& Hall, 2000; La Rocca, 2015), tourism makes people with different lingual and cultural backgrounds meet and do transactions. Consequently, tourism peripheries turn into multilingual space and people in the area deliberately choose language(s) to carry certain functions; a phenomenon which is well captured by linguistic landscape (henceforth LL) study. Landry and Bourhis (1997:25) propose LL as "The language of public road signs, advertising billboards, street names, place names, commercial shop signs, and public signs on government buildings combine to form the linguistic landscape of a given territory, region or urban agglomeration". In multilingual setting, as Bender (2021) concludes, linguistic landscape helps to illustrate many relationships existing between language, society and place. Gorter (2013) confirms that using LL as a source of data helps us to make meaning for societal multilingualism. This interpretation is made possible for LL shows visibility and salience of languages in a given territory. Sciriha (2017) explains that both visibility and salience in LL are interpreted through the observation of the frequency of the presence of language(s) and the profile of the language(s) dominance. A visibility of certain languages in LL serves symbolic and informational functions. Symbolically, LL represents social realities which inform the power or strength, and status of the competing language groups (Landry \& Bourhis, 1997; Spolsky \& Cooper, 1991). The choice of certain languages in LL showcases socio-cultural identity of the ethnolinguistic groups, positive attitudes to the use and the users of the language (Barni \& Bagna, 2010). Thus, scrutinizing the language(s) used on public displays sheds some light on how languages in multilingual spaces are perceived, contested, and negotiated by their users.

The significance of LL study has been pioneered by the publication of Landry and Bourhis (1997) which elaborate the concept of LL, its relation with ethnolinguistic vitality, and the evidence showing how the perceived vitality of language affected the behavior of language used by French Canadian minorities across Canada. One underpinning proposition related to LL highlighted in the paper is that languages presented in LL are deliberately selected to express informational and symbolic functions which mark the relative power and status of the linguistic community in a given territory. Ben-Rafael, Shohamy, Amara, and TrumperHecht (2006) add that linguistic composition in LL, however enigmatic, is used as symbolic construction of the public space. This is to say that the languages present in the linguistic combination do not necessarily 
reflect their existence in the community linguistic repertoire, rather, the presence of those languages on public signs are used to construct certain symbols for the space e.g. the use of English in Hebrew-dominated public signs in Israel was used as status symbol. Another case of the symbolic functions conveyed through LL is elaborated in Zhang and Chan (2017) where the choices of languages of shop names in Macao symbolically construct implicit cultural values and ecosystems such as 'traditional vs. modern' and 'East vs. West'.

To account for the constructed symbols in public space, the interpretation of social actors' behavior is required (Barni \& Bagna, 2015; Ben-Rafael et. al, 2006). In Ben Rafael et.al (2006) a framework which is adapted from three different traditions of sociological theories of social actions; 'Bourdieusard' perspective (Bourdieu, 1983; 1993), presentation-of-self and primordialist perspectives (Gofmann, 1963; 1981), and good-reasons perspective (Boudon, 1990) is proposed. Pierre Bourdieu (1983, 1993) in Language and Symbolic Power asserts that language is never a neutral means of communication but an instrument of power. Linguistic practices do not take place in a vacuum but embedded socio-historically in its conditions of production. As language is seen as socially constructed, it is where relations of symbolic power are actualized in forms (Bourdieu \& Wacquant, 1992). When related to the interpretation of LL, Bourdieu's perspective sees the forms of the linguistic composition as the product of power dynamics between the dominant and subordinate group. Ben-Rafael and BenRafael (2015) reaffirm that power is the underlying principle shaping the panorama of LL; this principle, for example, affects the social actors to exclude or to include certain languages in the LL panorama.

The presentation-of-self and primordial perspective interpret the forms of LL as the product of community self-embedded attempt to the public space. Goffman (1963, 1981) views that LL makers aim at targeted goals by presenting how they appear to form images to imprint their visibility by showcasing how they are different from others by accentuating their-self. LL in this view is created to seduce potential clients for example passers-by in the area of tourism or business. Their self-presentation is achieved by disassociating themselves from others or by staying in contrasts from others who are similar in purpose (i.e. different cafes but serve similar coffees). Self-struggling for presentation is to draw public attention. From this, it is hypothesized that their identity markers are to be present in the panorama of LL. Ben-Rafael and BenRafael (2015), for example, found that migrant communities make use of LL to create a unique identity which is intended to distinguish a certain migrant group from others.
As LL items are created to be successful to attract clients, LL normally gauges in foreseeing the clients' motivation and provides them with rational contemplation (Ben-Rafael, 2009). Boudon (1990, 2003, 2007) sees LL to portray the makers' interests attached to the language uses. The good-reasons perspective explains the forms of LL as the actors' attempt to attain certain goals or interests on the public, which is to gain expected influence of the public signs on the readers i.e. attractions, and cosmopolitan impression. The use of foreign language such as English in the LL, for instance, tells the prestige attached in the hope of attracting clients.

Central to many investigations about LL is the distinction between the official and non-official signs since the variable has resulted in different characteristics of languages used on public display. The first is often referred to as 'top-down' structure and the latter is 'bottom up' structure (Nikolaou, 2017). The 'topdown' structure analyzes the language(s) used by government offices which are characterized by the rigid imposition on the language stipulated by government policy. Tufi and Blackwood (2010) revisit the concept of what is classified as 'top down' structure and claims that transnational corporations which have the power to impose their language policies on their branches should be included in 'top-down' structure. The 'bottom-up structure' is the investigation to the non-official signs e.g. local shop-fronts which are often characterized by their non- compliance to government language policy. Landry and Bourhis (1997) clarify that both official and commercial signs contribute to the shaping of LL in public space. However, they add that analyzing the non-official sign is, more often than not, resulted in a wider spectrum of language use because they realistically reflect diverse linguistic and cultural backgrounds in a given territory. This is to say that doing the 'bottom up' investigation better captures the societal multilingualism in a community. The exploration of 'good-reasons' and 'self-presentation' principles, in addition, is more accentuated through the observation of the bottom-up signs (Nikolaou, 2017)

One of the bottom-up structures is shop signs or shopfront advertisements (Schlick, 2003 in Edelman, 2009) which function to persuade customers to buy products or services available in the stores. In these signs, the patterns of textual arrangements are identified as primary text and secondary text (Nikolaou, 2017). Primary text contains proper names or proper nouns which take examples such as shop names, brand and product names and names of residents and other text (Edelman, 2009). An example for a proper name and other texts which are combined is, Gezond Voordeel bij De Tuinen (Dutch, "healthy profit at De Tuinen"). While, secondary text is information about the product, 
special offers, and opening hours. The inclusion of proper names in the analysis of LL describes the multilingual characters of LL of which it can tell the attitude and objectives of the LL actors toward their selection of language in the proper names.

The cultivation of rich multilingual practice in LL is also the case of Bali. Bali tourism industry has undergone such major development and it has arguably grown into the most popular international tourist destination in Indonesia. Hirschmann (2021) has recorded that as many as 6.9 million foreign tourists visited Bali. The vast progress of Bali tourism has generated a transformation of its community; various economic activities in Bali has direct and indirect linkage to tourism (Antara \& Sumarniasih, 2017). This has opened ways for diverse and complex multilingual practices in Bali tourism peripherals. The multilingual practices in Bali tourist areas are induced by some factors. The first and foremost is the entrance of tourists, prominently international ones, bringing their lingual backgrounds with them and interacting through the transactions with the locals. Mardiastuti (2019) reported that tourists from China and Australia are on the top two, constituting almost $50 \%$ of the whole body of foreign tourist number in Indonesia aside from India, England and Japan. Another factor contributing to multilingual practices in Bali is the local migration to Bali for those who seek for job opportunities in Bali. Ever since the tourism industry in Bali bloomed, many people mainly from the neighboring islands (e.g. Java, Lombok) choose to reside in Bali and make a living there bringing their different language backgrounds.

Reading multilingualism in the tourism area through LL has been extensively done by several researchers. Nikolaou (2017) studies language aspects of 621 shop signs in eleven streets of the capital Athens and Kalithea municipality. Drawing on Spolsky and Cooper's three conditions of language choice (1991), Ben-Rafael's (2009) four structuration model to explain the processes and the agents involved in the construction of LL, and Kress and van Leeuwen's visual semiotics to study the meaning of LL visual signs $(1996,2006)$, the study revealed that strong multilingual signs are present in the findings. The shop signs related to retail shops, food and drinks describe English preferences while for entertainment, financial establishment, and professional services describe equal use of Greek and English. The use of multilingual characters present in the LL also revealed that the signs were meant to be more symbolical than informational to project a cosmopolitan and chic look. Inal, Bayyurt, Özturhan and Bektas (2020) reported the language choices present on the shop-fronts in some streets in various districts of Istanbul. In this study, 51 shop- fronts were collected and analyzed. They reported that Istanbul has moved toward a more multilingual area which was indicated by the combinations of Turkish, English and Arabic on the shop-fronts. Turkish was considered as a more powerful language among the three seeing from its percentage of appearance and how it was positioned on the shop-fronts. English also frequently appeared to communicate with the tourists as the locations where the shop-fronts were collected from were multicultural tourist destinations. Arabic started to appear in the LL panorama of the areas because of the increase of the number of immigrants and Arabic refugees in Istanbul. Another study in Beirut by Karam, Warren, Kibler, and Shweiry's (2020) discussed 128 private store fronts in relation to the absence of certain local scripts, Armenian and Arabic, and the presence of international brand names to reflect and project the changing identity of old Beirut. They concluded that the absence of Arabic from the Beiruti streets was equivalent to weakening of Beiruti identity, and the presence of international retailers in the shop fronts contributed to building images of being transnationally connected.

In the context of Indonesia, few LL studies have been conducted reporting the coexistences of languages and the profile of their visibility and salience in different settings e.g. education setting (Andriyanti, 2019), and tourism setting (Da Silva, Tjung, Wijayanti \& Suwartono, 2021). Considering the magnitude of the tourism industry in Bali, the multilingual practices as reflected on the LL panorama in Bali tourism peripheries are expected to be super diverse. LL in Bali has been examined by focusing on the language compositions of outdoor signs in Ubud (Mulyawan \& Maharani, 2019) and Desa Kuta (Mulyawan \& Erawati, 2019). The few reports on LL panorama in Bali leave a gap to fill, especially in the area focusing on the principles driving the emergence of linguistic compositions in multilingual Bali tourism peripheries. In regard to giving contribution to the discussion of LL from the sociolinguistic and sociology perspectives, this research tries to describe the language selections in Bali tourism areas as reflected on the shop signs and the principles driving such choices. More specifically the questions are formulated as follow:

1. How does the degree of salience and visibility of languages in Bali look like?

2. What principles drive the emergence of such degree?

\section{METHOD}

This study scrutinized the choices of language(s) to be presented on shop-fronts and the text types. To portray the profile of salience and visibility of languages 
present on the shop-fronts and elaborate the principles of such portrait, explanatory sequential mixed methods design (Creswell \& Creswell, 2018) was used for this study. This design is intended to have the qualitative data to elaborate in detail the quantitative results. The studies in LL have suggested that shop signs are seen as the 'bottom-up landscape' (Backhaus, 2007; BenRafael, 2009); that they potentially showcase more diversity in the language uses (Landry \& Bourhis, 1997; Gorter \& Cenoz, 2008) and that they are used by the local businesses to show the owners' identity (Shang \& Guo, 2017). To specify the local businesses used as the unit of analysis of this study, this study followed the 'top-down' signs criteria restructuration proposed by Tufi \& Blackwood (2010) which propose the inclusion of global brand shop signs in addition to the government signs as they impose certain language policies over the others at trans-national level. By considering this, all branches of international business brands were excluded from the picture of LL panorama of private shop signs in tourism peripheries in Bali. The shop signs analyzed were name boards; this research made observation on the main boards put at the shop fronts and they might vary from showing names and slogans to carrying informational value to the shops

\section{Data Collection}

To collect the pictures of the shop signs, two data collectors residing in Bali were assigned to collect the pictures of the shop boards around the peripheral areas of the four famous beach tourism areas in Bali: Kuta beach, Padma beach, Sanur beach and Segara beach. These tourism peripherals were chosen because beach tourism was the main attraction in Bali Island and these beaches were among the more visited beaches compared to others. The massive numbers of the tourists visiting these beaches have induced the growth of the local businesses in the peripheral areas. The pictures were taken in their peripheral areas; those were the streets very near to the gates leading to the beach (in the range of 300 meters outside the entrance gate). The photos were taken using either camera or mobile phone camera with the assurance of high quality photos for further analysis. The two data collectors were assigned to different areas to avoid duplication in the data. The photos were collected for two weeks in the month of June 2020. The photos were collected along with the information of the streets and the description of the situations where they were displayed (e.g. whether they were usually visited by international or local tourists). When the data were collected, another round of checking process to affirm its clarity and zero practice of duplication were added. From these processes, as many as 500 photos of shop-fronts were collected and analyzed.

\section{Data analysis}

The categorizations of the data were made on the ground of the similarities of the types of the businesses. All photos were categorized based on their types and each photo was coded using their type of business categories and numbered to ease the tracing process of the shop signs.

Table 1. Types of businesses found in LL of Kuta beach, Padma beach, Sanur beach, and Segara beach.

\begin{tabular}{clc}
\hline Code & Types of Businesses & Numbers of Shop Signs \\
\hline A & Barber shop & 5 \\
B & Beauty salon & 80 \\
C & Clubs & 4 \\
D & Small eatery & 23 \\
E & Groceries & 10 \\
F & Hand-craft shops & 129 \\
G & Laundry & 2 \\
H & Optics & 1 \\
I & Pet shops & 1 \\
J & Car rentals & 7 \\
K & Restaurants and cafes & 152 \\
L & Fashion stores & 20 \\
M & Tattoo parlors & 40 \\
N & Tour service & 26 \\
\hline
\end{tabular}

To support the analysis of the data, the calculation of the monolingual, bilingual, and multilingual signs were done. Through this calculation, the profile of multilingualism in Bali tourism peripheries was described. More importantly, the percentages of the appearances of each language presented on all shop signs were calculated and interpreted. Through the percentages, the images of visibility and salience of each language found in the display were made clear. To make sense of the extent of the visibility and salience of particular languages in Bali tourism peripheries, the forces behind such emergence need to be explained. Drawing on the hypothesis proposed by Bourdieu (1983, 1993), the unequal distribution of power in these areas was described by looking at the profile of the demography of the population residing and doing activities in the sites. Through the extent of visibility and salience of the local languages on shop signs, the representativeness of the local community was explained. This explanation was made possible by using Goffman's (1983) hypothesis which argues that ethnic community made their identity visible in public scenes. Drawing from the domination of certain languages on the public sign, the constructed symbols which the makers try to create through the use of a more dominant or 'powerful' language were explained. As Scollon and Scollon (2003) argue that code preference does not always index the one existing and dominantly used in community linguistic repertoire, it is used to construct symbols desired by the 
Table 2. The number of appearances of languages on shop-fronts.

\begin{tabular}{|c|c|c|c|c|c|c|c|c|c|c|c|c|c|}
\hline Types of business & Indonesian & English & Balinese & Indian & Japanese & Hawaiian & Turkish & Arabic & Chinese & Spanish & Italian & French & Vietnamese \\
\hline Barber shop & 1 & 5 & & & & & & & & & & & \\
\hline Beauty salon & 13 & 86 & 10 & 4 & 3 & 3 & 1 & & & & & & \\
\hline Clubs & 1 & 4 & & & & & & & & & & & \\
\hline Small eateries & 21 & 19 & 1 & & & & & 2 & 1 & & & & \\
\hline Groceries & 5 & 8 & & & & & & & & & & & \\
\hline Hand-craft shops & 40 & 135 & 20 & & 5 & & & & & 1 & & & \\
\hline Laundry & 1 & 2 & & & & & & & & & & & \\
\hline Optics & 1 & 1 & & & & & & & & & & & \\
\hline Pet shops & & 1 & & & & & & & & & & & \\
\hline Car rentals & 3 & 4 & & & & & & & & & & & \\
\hline Restaurants and cafes & 55 & 141 & 5 & 4 & & & & 5 & 1 & 5 & 12 & 1 & 1 \\
\hline Fashion stores & 4 & 20 & & & & & & & & & & & \\
\hline Tattoo parlors & 2 & 40 & & & & & & & & & & & \\
\hline Tour service & 7 & 26 & & & & & & & & & & & \\
\hline Total number of appearance & 154 & 492 & 36 & 8 & 8 & 3 & 1 & 7 & 2 & 6 & 12 & 1 & 1 \\
\hline In percentage $(\%)$ & 21,12482853 & 67,48971193 & 4,938271605 & 1,097394 & 1,097394 & 0,411523 & 0,137174 & 0,960219 & 0,274348 & 0,823045 & 1,646091 & 0,137174 & 0,13717421 \\
\hline
\end{tabular}

makers. This hypothesis was earlier explained by Boudon (in Ben Rafael et al, 2006) that code preference is driven by 'good reasons' that is the expected influence on the clients. In this research, to dig the good reasons, we attempted to match the dominantly preferred code with the possible influences it can create on the mind of the international tourists as international tourists constitute bigger portion of the overall number of tourists in Bali.

\section{The practices of multilingualism as reflected on shop-fronts in Bali tourism peripheries}

Of all 500 shop-fronts which were collected and analyzed, 307 (61.4\%) signs were monolingual signs, 184 signs (36.8\%) were bilingual and 9 signs (1.8\%) were multilingual. To obtain the clear vision of the degree of salience and visibility of languages found on the shop-fronts in these areas, the following table is presented.

The multilingualism in Bali tourism peripheries as reflected on the shop-fronts was constituted by the domination of English (67.48\%); Indonesian as the national language and Balinese as the language of the locals were found as less visible and salient. Some other foreign languages-Indian, Japanese, Hawaiian, Turkish, Arabic, Chinese, Italian, Spanish, French, and Vietnamese- were also visible but not as visible and salient as the three aforementioned languages. The other foreign languages' visibility was mainly found in big cafés and restaurants as names of the restaurants or the specialty menu. In Bali, the speakers of these languages are not big in numbers; their presence in LL panorama must not be for indexing the existence of the community. Leeman and Modan (2009) call them as 'floating signifiers' which are used to signify or to sell anything related to the culture of the language. Thus, these foreign languages' presence in the landscape of Bali tourism peripheral areas is used to index their culture; that is to sell things that are particular to their culture only, in this case, food.

The visibility and salience of English in the landscape of these areas were very intense, if not almost omnipotent. Drawing from the analysis of the number of appearances of English and its placement, it was found that English wass not only dominant in bilingual signs but it was also massively dominant in monolingual sign. The use of all-English- signs were of bigger portion than all-Indonesian signs. The domination of English in monolingual sign was apparent in all types of businesses except for the small eateries signs. English also appeared in all bilingual shopfronts.

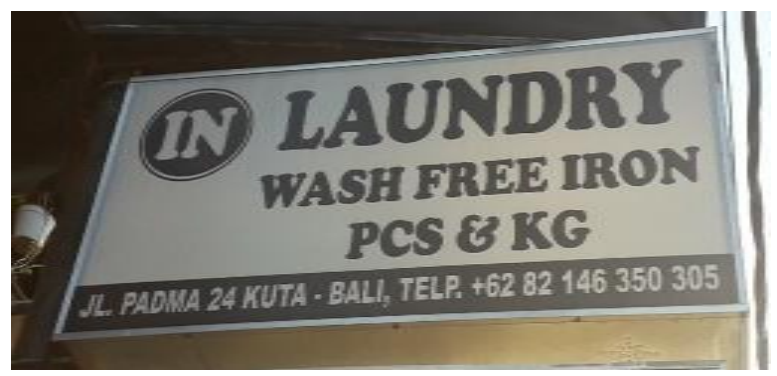

Figure 1. A laundry shop which uses English, 2020 (personal collection)

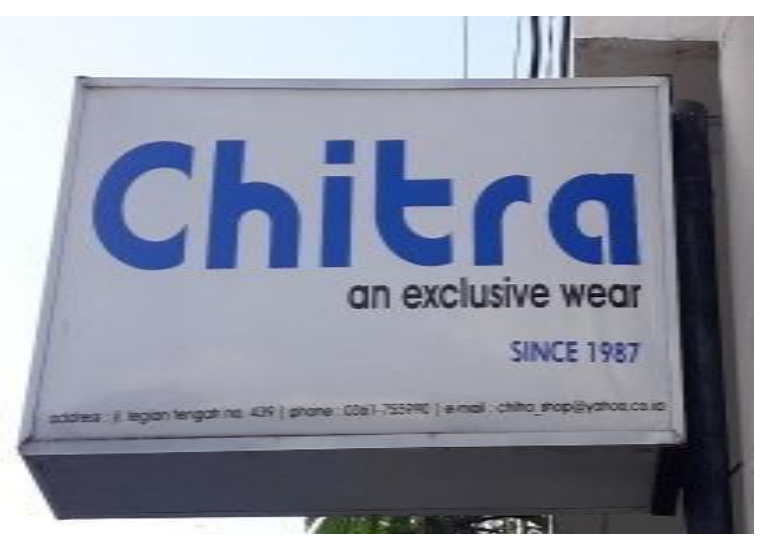

Figure 2. A fashion shop which uses Indonesian as the name English for information, 2020. (Personal collection)

In the case of bilingual signs, the degree of English visibility and salience was not only observable through the selection of English over other languages, but it was also accentuated by the pattern of its placements on the sign. English was used dominantly in all types of text of the shop-fronts; it was placed as brand names in some bilingual signs and was used extensively in the 
type of business names. The use of English was also incomparably dominant in information text presented on the signs, much more extensively than the use of Indonesian as the national language used in the area. English had a total domination in the taglines of the shop as all taglines were written using English although the shops use Indonesian brand names. Contrary to the domination of English in Bali tourism peripheries LL, Indonesian language and Balinese were less visible and salient. Indonesian language appeared in monolingual and bilingual signs and was placed as brand names and as information text. Indonesian language did not appear in type of business text except for small eateries where the word of 'warung' was used. Balinese appearance on shopfronts was relatively low and it was only placed as the brand of the shop's name. Balinese was never used as the information text and type of business text. Furthermore, no Balinese taglines were found.

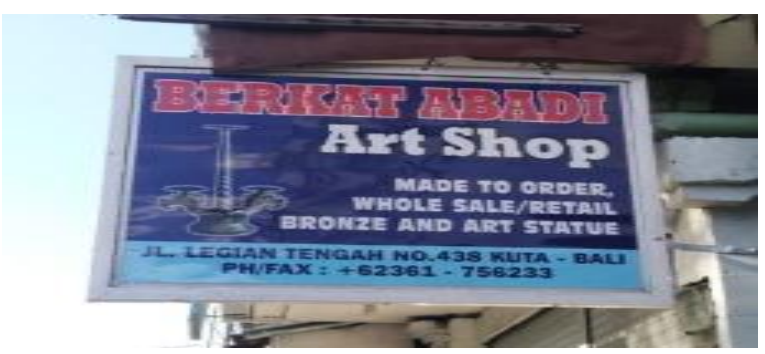

Figure 3. A sign for a hand-craft shop which uses English in type of business and information text, 2020 (Personal collection)

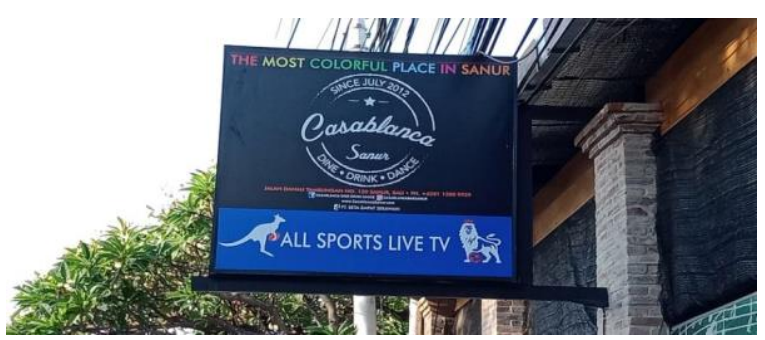

Figure 4. A sign for a café which uses English slogan in a monolingual board, 2020 (Personal collection)

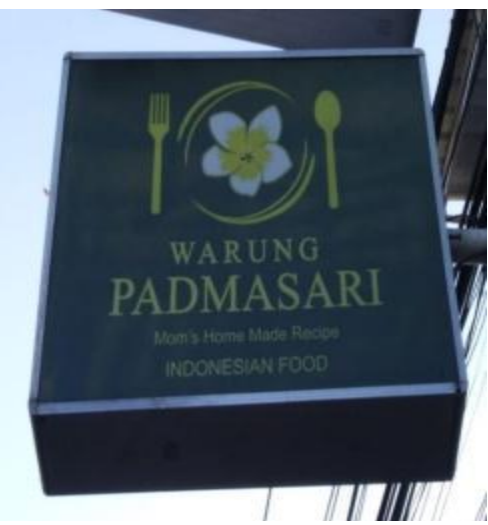

Figure 5. A sign for a small eatery which uses English slogan in bilingual sign, 2020 (Personal collection)

\section{What principles drive such degree of salience and visibility?}

Drawing from the higher percentage of the use of English in monolingual and bilingual signs, it is inferred that English is the dominant language in these areas. Its ubiquity on shop-fronts proves that English enjoys a higher 'status' and is deemed as more 'vital' than other languages used in these areas particularly Indonesian as the national language and Balinese as the language of the locals. The higher status and the vitality of English in Bali peripheral areas reflect the power that is attributed to English in these peripheral areas. This is the exact case of what Bordieu (1993) asserts as power-relation motive in LL. From this point of view, the privilege that English enjoys in the LL of Bali tourism peripheries is not to be interpreted as the immediate index of the existence of the English speakers in the community as the locals dominantly use Indonesian and Balinese for communication. Rather, it is better interpreted as how the locals use this perceived power to achieve expected goals in the context of the tourism industry. In the context of LL in Bali tourism peripheries, thus, we argue that the principles of power relation and good reason are more prevalent than the self-presentation principles.

We observe that there are some motives for elevating English to such degree of salience and visibility in these areas. Looking at the composition of the tourists visiting Bali, the international tourists outnumber the domestic tourists every year. This number has helped the local businesses to identify the major clients who drive their economy. McCormick and Agnihotri (2009) reveal that choice of languages is meant to be for passers-by or readers who are considered important enough by the locals to become their targeted clients. English has enjoyed the status of global lingua franca, and is perceived by Balinese locals as the language of universal readership. The fact that Chinese tourists constitute more than $25 \%$ of the body of international tourist numbers does not waver the domination of English. The appearance of Chinese language in the shop-fronts is very rare; and it only appears in the brand of the shop in the form of transliteration. Mandarin Chinese and its Romanized form never appear in the information text or taglines. This might be due to the high complexity of Mandarin Chinese that makes the locals rarely use them on shop-fronts. However, the fact that this big number of the customers does not make the locals cater their language on their shop names implies that the local business runners in Bali tourism peripheries try to impose the privilege that English has to non-English speakers; showing that local business runners have put the efficiency and economy motives at the front. 
The almost omnipotent salience and visibility of English in Bali tourism peripheries do not only correspond to the economy-driven power relation in the areas, but it also showcases the associations the local business runners try to create. Drawing from Boudon's (1990) principle of good reason, these associations are made evidential by the way English is placed on these shop-fronts. Landry and Bourhis (1997) proposed that there are two ways of what signs are presented on LL for; delivering the informational value, and symbolical value. The types of business and the information text of the shop-fronts, according to Nikolaou (2017), carry informational value while the brands of the shops and shops' taglines, arguably, carry symbolical value. Seeing the priority on the economic motive and the target of international audience, we argue that the reasons for 'cosmopolitan' and 'modern' associations are the ones desired. Curtin (2014) has confirmed that to construct the association of cosmopolitanism requires locals' competence and use of English to accommodate international travelers reflected through $\mathrm{LL}$.

\section{DISCUSSION}

The results clearly indicate multilingualism in Bali tourism peripheries, however, there is a strong polarization of the community group to lean on English as the more important language. The appearance of other foreign languages, although visible, is not salient. The domination the use of English does not only overweigh other foreign languages, but also is favored over the national language, Indonesian, and their local language, Balinese. In Japan, Backhaus (2007) observed different LL trend in which the non-official signs used more balanced composition of Japanese and English as well as other foreign languages. This trend is driven by solidarity motive that is the desire to show solidarity to things which are non-Japanese. The study by Da Silva, Tjung,, Wijayanti, \& Suwartono (2019) which took place in Malioboro, the most famous tourist street in Yogyakarta, found that Indonesian is prevalent in number and in linguistic composition in both commercial and regulatory signs due to the perception of readership that mainly targets Indonesian speakers. What happens in Bali tourism peripheries' LL is, on the contrary, a language choice which is driven by power relation motive. With Indonesian and Balinese used as the languages for locals' communication, the choice for English is driven by the power, efficiency, and the privilege English has in the global market nowadays. The power that English has as a global lingua franca leads the business runners to believe that it is the only language effective for international readership. This can be concluded from the total domination of English in the informational texts. Tourists in these areas are expected and are imposed to accept English as the main tool for communication. This is not always the policy taken in other tourist areas. $\mathrm{Lu}, \mathrm{Li}$, and $\mathrm{Xu}(2020)$ report that in the case of traditional village tourism in China, more diverse languages present in its LL to show its transformation to fit into global market. The multilingualism in this kind of tourism, however, paints a strong image for the local culture through the dominant use of Chinese characters; uses English to attract young tourism; and accentuates the use of Korean and Japanese languages to garner more attention from their Korean and Japanese clients. The panorama of LL in Bali tourism peripheries, on the other hand, reflects different perception of their target clients. Although Chinese tourists contribute substantially into the overall body of the international tourists which make them obvious target clients, the visibility of Chinese language in LL in Bali tourism peripherals is very rare. This condition accentuates the hypothesis that the local business owners impose English as the only language of communication for all speakers for the sake of efficiency.

The domination of English in non-informational texts of the shop-fronts in the Bali tourism peripheries accentuates the principle of good-reason (Boudon, 1990) over the self/ethnic representation (Ben-Rafael \& Ben-Rafael, 2015; Goffman, 1963, 1981). The brand texts and taglines are used to build the image of the shops. Indexing the identity as Balinese is also a motive found in this LL, however, the very rare appearance of Balinese in the types of text means that other images other than the locality are being constructed through the use of English. Ross (1997) explains that today English is seen as an attractive and fashionable language, When using English names in business signs, some perceived positive imageries are constructed such as making the business as the part of international scene, the up-to-datedness of the business, and the image of a business that continuously following the trend. Coluzzi (2009) reports that these motives are found in the case of Italian streets LL especially in Udine and Milan where shop names dominantly use English to make these associations. Gúrkova (2005) affirms that in Macedonia, where English is used comparably similar with countries in south-east Asia, English names and slogans function more than just targeting consumers who are proficient in English; rather, English is used to make certain associations, in this case indicating western consumerism. In the context of shop signs in Bali tourism peripheries, the analysis to the placement of the texts shows that English is used in all slogans, more interestingly; it is also used in all shops that use Indonesian brand names. This implies that the slogans 
are not only used to be more visible and understandable for international readers, but are also used by the locals shop owners to make associations that can only be achieved by using English but not by local names. In the context of Bali tourism peripheries' LL, almost all types of business texts use English e.g. 'resto and café'; 'dining and grill'; 'art shop';'barber shop'; 'fashion collection', as a way to communicate the businesses to international market. Additionally, the association of being the part of international scene is also reflected on the use of taglines where the shops use English dominantly to showcase their shops' mottos e.g. 'Come As A Guess, Leave As A Friend'; 'Don't Worry Be Happy'; 'Today Is Going To Be A Great Day'; 'The Taste Is Never Lies', etc. The want for international association is accentuated here considering the fact that English taglines also appear even in the shop-fronts that use Indonesian brand; as if confirming their local shop identity as modern and being a part of international scene.

\section{CONCLUSION}

Grounded on the observation to the compositions of languages and the types of texts displayed on shopfronts in Bali tourism peripheries, this research made a profile of the salience and visibility of the languages co-existing in LL of the area to see how the languages are perceived by the local shop owners in regard of their vitality. English is found as the most salient and visible, almost omnipotent, language in Bali. English is present in almost all of the shop-fronts with or without the national and local language as its counterparts which shows that it is perceived as the most vital language in these areas. This LL profile is different from the profile in tourist area in Yogyakarta (Da Silva, Tjung,, Wijayanti, \& Suwartono, 2019) where Indonesian is perceived as the most vital language in commercial signs. This study, thus, portrays the different profile of language vitality in multilingual Bali tourism peripheries. The report by Mulyawan and Erawawti (2019) also found similar results where English has as strong domination in the panorama of LL in Desa Kuta, Bali. However, the forms of the domination and the sources of its domination were not the focus of the research. In this study, the prevalence of English is also observed through its domination in types of text displayed on the shop-fronts; the appearance of English names as brands is relatively frequent and the slogans were all written in English although the brand names are in Indonesian or Balinese. This shows that English is deliberately chosen to make beneficial associations for the shops, that is, to build affiliation with international business scene and to establish the impressions of their local businesses as modern, updated ones. English is also used dominantly in the text carrying informational value, much more dominant than the use of Indonesian as the national language. This shows that local shop owners target and prioritize international readership, and perceive English as the most powerful language to achieve the target.

The power that is perceived and attributed to English is very strong that the domination leads to the imposition of the use of English to all tourists no matter what their language background is. This is shown in how the domination of English neglects the fact that Chinese tourists constitute a large body to the international tourist compound in Bali; Mandarin is rarely found and Romanized Mandarin is also not found in the LL of Bali tourism areas. The integration of Mandarin Chinese on shop-fronts can index solidarity to this big body of Chinese tourists. This move is adopted in multilingual Tokyo (Backhaus, 2009) where foreign languages are deliberately presented by the local shop owners to mark solidarity to non- Japanese. In these areas, the principle of power which is driven by effectiveness and economy motive also outweighs the presentation of local identity in this area. Although Balinese is found in the panorama of LL in these areas, it is, arguably, under-represented. Its visibility is the lowest among English and Indonesian and it only presents in the names of shop brands in few shopfronts. No Balinese slogans are found in the LL of these areas.

It is important to note, however, that the LL portraits captured in this research might be specific to the context of beach tourist destination peripheries as the local business shop-fronts were captured in the area outside the beach entrance gates. Thus, it is recommended that the future researcher interested in doing similar study completes the portrait by expanding the areas of LL panorama. It is also recommended that the future researcher enriches the study on the motives of language choices made by local shop owners by administrating the interviews. Through these two things, the study of language vitality in Bali can be more profoundly reported.

\section{ACKNOWLEDGEMENTS}

We thank the Institute of Research and Community Engagement of University of Jember which provides supporting funding for this research and also all members of Research Group English in a Perspective of Lingua Franca, English Department, Faculty of Humanities, University of Jember for early discussions. 


\section{REFERENCES}

Andriyanti, A. (2019). Linguistic landscape at Yogyakarta's senior high schools in multilingual context: Patterns and representation, Indonesian Journal of Applied Linguistics, 9(1), 85-97. https://doi.org/10.17509/ijal.v9i1.13841

Antara, M. \& Sumarniasih, M. S. (2017). Mapping of featured micro-small-medium enterprises in Buleleng Regency, Bali, Indonesia. International Journal of Economics and Financial Issues, 7(4), 49-53.

Backhaus, P. (Ed.). (2007). Linguistic landscapes: A comparative study of urban multilingualism in Tokyo. London: Multilingual Matters.

Barni, M., \& Bagna, C. (2010). Linguistic Landscape and Language Vitality. In E. Shohamy, E. Ben Rafael, \& M. Barni (Eds.), Linguistic Landscape in the City (pp. 3-18), Bristol: Multilingual Matters.

Barni, M. \& Bagna, C. (2015). The critical turn in LL: New methodology and new items in LL. Linguistic Landscape and International Journal, l(1-2), 6-18. https://doi.org/10.1075/11.1.1-2.01 bar

Bender, M. (2021). Linguistic Landscape. In Stanlaw, $\mathrm{J}$ (Ed.), The international encyclopedia of linguistic anthropology (pp.1-7). New Jersey: John Wiley \& sons.

Ben-Rafael, E., Shohamy, E., Amara, M. H, \& Trumper-Hecht, N. (2006), Linguistic landscape as symbolic construction of the public space: The case of Israel. International Journal of Multilingualism, 3(1), 7-30. https://doi.org/10.1080/ 14790710608668383

Ben-Rafael, E. (2009). A sociological approach to the study of linguistic landscapes. In E. Shohamy \& D. Gorter (Eds.), Linguistic landscape: Expanding the scenery (pp. 40-54). Routledge: New York.

Ben-Rafael, E. \& Ben-Rafael, M. (2015). Linguistic landscapes in an era of multiple globalizations. Linguistic Landscape, 1(1-2): 19-37. https://doi. org/10.1075/11.1.1-2.02ben

Boudon, R. (1990). La place du désordre. Critique des théories du changement social. Paris: Quadrige.

Boudon, R. (2003). Raison, bonnes raisons. Paris: Puf.

Boudon, R. (2007). Essais sur la Théorie Générale de la Rationalité: Action sociale et sens commun, Paris: Puf.

Bourdieu, P. (1983). La distinction: Critique sociale du jugement. Paris: Les Editions de Minuit.

Bourdieu, P. (1993). The field of cultural production: Essays on art and literature. New York: Columbia University Press.

Bourdieu, P., \& Wacquant, L. J. D. (1992). An invitation to reflexive sociology. Cambridge: Polity Press.
Coluzzi, P. (2009). The Italian linguistic landscape: the cases of Milan and Udine, International Journal of Multilingualism, 6(3), 298-312. https://doi.org/ 10.1080/14790710902935930

Creswell, J. W., \& Creswell, J. D. (2018). Research design: Qualitative, quantitative, and mixed methods approaches (5th ed.). Sage Publication: Califonia.

Curtin, M. (2014). Mapping cosmopolitanisms in Taipei: Toward a theorisation of cosmopolitanism in linguistic landscape research. International Journal of the Sociology of Language, 228, 153-177. https://doi.org/10.1515/ijsl-2014-0009

Da Silva, A., Tjung, Y.N., Wijayanti, S.H., \& Suwartono, C. (2021). Language use and tourism in Yogyakarta: The linguistic landscape of Malioboro. Wacana, 22(2), 295-318 https://doi. org/10.17510/wacana.v22i2.721

Edelman, L. (2009). What's in a name? Classification of proper names by language. In E. Shohamy \& D. Gorter (Eds.), Linguistic landscape: Expanding the scenery (pp. 141-154). New York, NY: Routledge.

Goffman, E. (1963). Behavior in Public Places, New York: Free Press.

Goffman, E. (1981). Forms of Talk, Philadelphia: University of Pennsylvania Press.

Gorter D., \& Cenoz J. (2008) Knowledge about Language and Linguistic Landscape. In: Hornberger N.H. (Ed.), Encyclopedia of Language and Education. Boston, MA: Springer.

Gorter, D. (2013). Linguistic Landscapes in a Multilingual World. Annual Review of Applied Linguistics, 33(1), 190-212. https://doi.og/10.1017/ s0267190513000020

Gúrkova, A. 2005. 'Makedonskiot jazik i jazikot na masovnata kultura.' In Proceedings of the XXXII Conference of the XXXVIII International Seminar for Macedonian Language, Literature, and Culture, pp. 145-150.

Hirschmann, R. (2021, April 7). Number of foreign tourist arrivals in to Bali, Indonesia 2011-2020. Statisa. https://www.statista.com/statistics/9768 42/foreign-tourist-arrivals-numbers-bali-indonesia

Inal, D., Bayyurt, Y, Özturhan, M., \& Bektas, S. (2020). Multilingualism in the linguistic landscape of Istanbul. World Englishes, 40(2), 280-289. https://doi.org/10.1111/weng.12514

Karam, F. J., Warren, A., Kibler, A. K., \& Shweiry, Z. (2020): Beiruti linguistic landscape: An analysis of private store fronts. International Journal of Multilingualism, 17(2), 196-214. https://doi.org/ 10.1080/14790718.2018.1529178

Kress, G., \& van Leeuwen, T. (1996). Reading images: The grammar of visual design. London: Routledge. 
Kress, G., \& van Leeuwen, T. (2006). Reading images: The grammar of visual design (2nd ed.). London: Routledge.

Landry, R., \& Bourhis, R. (1997). Linguistic landscape and ethnolinguistic vitality. Journal of Language and Social Psychology, 16(1), 23-49. https://doi. org/10.1177/0261927X970161002

La Rocca, R. A. (2015). Tourism and mobility: Best practices and conditions to improve urban livability, TeMA-Journal of land use, mobility, and environment, 3, 311-330. https://doi.org/10.6092/ 1970-9870/3645

Leeman, J., \& Modan, G. (2009). Commodified language in Chinatown: A contextualized approach to linguistic landscape. Journal of Sociolinguistics, 13(3), 332-362. https://doi.org/10.1111/j.14679841.2009.00409.x

Lu, S., Li, G., \& Xu, M. (2020). The linguistic landscape in rural destinations: A case study of Hongcun Village in China. Tourism Management, 77(1). https://doi.org/10.1016/j.tourman.2019. 104005

Mulyawan, I. W. \& Erawawti, N. K. R. (2019). Linguistic landscapes in Desa Kuta, e-Journal of Linguistics, 13(2), 343-352. http://dx.doi.org/10.24843/ e-JL.2019.v13.i02.p12

Mulyawan, I. W. \& Maharani, S. A. I. (2019). Linguistic Landscapes: Cultural representation in Ubud, Bali, International Journal of Innovation and Research in Educational Sciences, 6(1), 84-89.

Mardiastuti, A. (2019, January 2). Turis China dan Australia Terbanyak Liburan ke Bali Sepanjang 2018. Detik. https://travel.detik.com/travel-news/ d-4368482/turis-china-dan-australia-terbanyakliburan-ke-bali-sepanjang-2018

McCormick, K. \& Agnihotri, R. K. (2009). Forms and functions of English in multilingual signage. English Today, 25(3), 11-17. https://doi.org/10. 1017/S0266078409990228
Nikolaou, A. (2017): Mapping the linguistic landscape of Athens: The case of shop signs, International Journal of Multilingualism. 14(2), 160-182. https://doi.org/10.1080/14790718.2016.1159209

Ross, N. (197). Signs of international English. English Today, 13(2), 29-33.

Scollon, R. \& Scollon, S.W. (2003). Discourses in Place: Language in the Material World. London: Routledge

Sciriha, L. (2017). The visibility and salience of Maltese in bilingual Malta's linguistic landscape. In B. Saade \& M. Tosco (Eds.), Advances in Maltese linguistics (pp. 225-244). Berlin: Gruyter De Mouton. https://doi.org/10.1515/978110565744010

Shang, G., \& Guo, L. (2017). Linguistic landscape in Singapore: What shop names reveal about Singapore's multilingualism. International Journal of Multilingualism, 14(2), 183-201. https://doi. org/10.1080/ 14790718.2016.1218497

Spolsky, B. \& Cooper, R.L. (1991) The Languages of Jerusalem. Oxford: Clarendon Press.

Tufi, S., \& Blackwood, R. (2010). Trademarks in the linguistic landscape: Methodological and theoretical challenges in qualifying brand names in the public space. International Journal of Multilingualism, 7(3), 197-210. https://doi.org/10. 1080/14790710903568417

Williams, A.M. \& Hall, C.M. (2000). Tourism and migration: new relationships between production and consumption. Tourism Geographies,2, 5-27. https://doi.org/10.1080/146166800363420

Zhang, H. \& Chan, B. H.-S (2017). The shaping of a multilingual landscape by shop names: Tradition versus modernity, Language and Intercultural Communication, 17(1), 26-44. https://doi.org/10. 1080/14708477.2017.1261674 